\title{
Kiai dan Pendidikan Toleransi di Pesantren
}

\section{Fajriyah, ${ }^{1}$ Mufiqur Rahman, ${ }^{2 *}$ Mo'tasim, ${ }^{3}$ Artamin Hairit, ${ }^{4}$ Ach. Sayyi, ${ }^{5}$ Afandi, ${ }^{6}$ Roro Kurnia Nofita Rahmawati ${ }^{7}$ \\ 1,2,4,5,7 IAI-Al-Khairat Pamekasan Madura, ${ }^{3,6}$ STIT Al-Ibrohimy Bangkalan Madura 1' fariampd.fr@gmail.com, ${ }^{2}$ mufiqurrahman@alkhairat.co.id, ${ }^{3}$ billahmutasim73@yahoo.com, 4artamin@alkhairat.ac.id, ${ }^{5}$ sayyi@alkhairat.ac.id, ${ }^{6}$ afandiabbas229@gmail.com \\ ${ }^{7}$ kurnianofita3110@gmail.com}

Received: 2021-04-03 Revised: 2021-07-23 Approved: 2021-07-30

*) Corresponding Author

Copyright $\mathbb{C} 2021$ Authors

\begin{abstract}
The kiai as a designer, implementer and controller of the course of education in the pesantren. Kiai determines the direction of a boarding school education. The attitude and character of the kiai determine the color of the pesantren education. This study is to describe particularly a role of Kiai in pesantren management patterns by promoting tolerance education as one of the Kiai's leadership styles in the pesantren. This research method uses qualitative methods with case studies. The data network was carried out by observation, interviews, documentation, and Focus Group Discussion (FGD). While data analysis using data reduction, display and conclusion. As well this study found a new model of tolerance education which a model of kiai cantered or a Model of kiai. First kiai became advisor and planner to set a education of tolerance based on multicultural view. Second, learning of tolerance delivered in the class integrated with the all the subjects, teachers should stated about tolerance during the class. And then the practice of tolerance accommodated by kiai including the community and santri activities as well kiai welcomed the tradition of community.
\end{abstract}

Keywords: Education of Tolerance, Kiai, Pesantren.

\begin{abstract}
Abstrak
Kiai sebagai perancang, pelaksana dan pengontrol jalannya pendidikan di pesantren. Kiai menjadi penentu arah sebuah pendidikan pesantren. Sikap dan karakter kiai menentukan warna pendidikan pesantren. Penelitian ini bermaksud mendeskripsikan peran kiai dalam pola kiai pesantren dengan mengedepankan pendidikan toleransi sebagai salah satu gaya kepemimpinan kiai di pesantren. Penelitian ini menggunakan metode kualitatif dengan jejaring data observasi, wawancara mendalam, dokumentasi, dan FGD. Sementara analisis data menggunaakan reduksi data, display data, dan penarikan kesimpulan. Penelitian ini menghasilkan sebuah model pendidikan toleransi yaitu model kiai centered atau berpusat pada keteladan kiai. Pertama kiai sebagai pengarah dan perumus memberikan rancangan dan rencana pendidikan berbasis pada pendidikan multi budaya dan sosial santri yang beragam. Tahap pelaksanaan pendidikan toleransi dimulai pada tahapan desain dan rancangan pembelajaran. Pembelajaran toleransi disampaikan di kelas secara integratif dengan semua mata pelajaran, guru harus menyampaikan pesan toleransi setiap mengajar. Kemudian praktik toleransi diakomodasi oleh kiai dalam kegiatan santri dan masyarakat.
\end{abstract}

Kata Kunci: Kiai, Pendidikan Toleransi, Pesantren. 


\section{Pendahuluan}

Indonesia adalah negara yang kaya dengan perbedaan, baik budaya, etnis, dan bahasa. ${ }^{1}$ Perbedaan tersebut membutuhkan sentuhan pendidikan yang mendukung dan merawat keberagaman tersebut. Desain pendidikan yang baik dengan nilai dan prinsip multicultural society menjadi diskursus dalam pendidikan nasional termasuk juga bagaimana pendidikan Islam menjawab tantangan ini. Sebuah tantangan mengelola pendidikan yang dapat menjawab persoalan-persoalan yang lahir dari diversitas sosial budaya dan geografis. ${ }^{2}$ Salah satu nilai yang harus ada dalam pendidikan berbasis multi budaya adalah nilai toleransi. ${ }^{3}$ Di mana nilai toleransi harus menjadi spirit utama dalam sebuah model pendidikan multi budaya dalam satuan pendidikan. Pesantren merupakan salah satu bentuk satuan pendidikan nasional yang mempunyai karakter khas yakni sebagai lembaga pendidikan keislaman asli nusantara yang menyimpan bentuk dan model yang unik dari satu pesantren dengan pesantren lainnya.

Kiai adalah pengarah atau sebagai pemimpin atau juga dapat disebut sebagai pembuat rumusan kebijakan pendidikan pesantren dari sebuah nilai dan budaya pesantren selama 24 jam yang terkonstruk di dalamnya sebuah kehidupan santri sejak bangun tidur dan tidur kembali. Artinya kultur dan budaya atau sub budaya pesantren tidak lepas dari peran kiai yang memiliki peran sentral dalam perwujudan karakter dan kekhasan sebuah pesantren. Termasuk juga membangun hubungan antar santri yang menurut Robert Putnam dalam Rahman disebut sebagai social capital yaitu sebuah hubungan antar individu dengan derajat kepercayaan yang baik antar santri. Menurutnya modal sosial ini adalah bagian urgen untuk mencapai sebuah tujuan proses pembelajaran. ${ }^{4}$ Kemudian Putnam menyebut tentang tiga langkah urgen dalam menanamkan budaya dan moralitas kepada santri, yaitu apa yang disebut dengan moral obligations yang artinya kepercayaan atau tanggung jawab moral. Kemudian social value yaitu sebuah nilai sosial yang membentuk sebuah konstruksi budaya dan kultur serta juga karakter moral santri. Selain itu, yang tidak kalah penting adalah social networks, yaitu sebuah jaringan sosial yang

\footnotetext{
1 Mohammad Mizan Habibi, "Islamic Education Curriculum Framework Development Based on Multicultural Values," International Journal of Management and Applied Science (IJMAS) 3, no. 5, (2017): 25-28.

${ }^{2}$ Habibi.

${ }^{3}$ Mufiqur Rahman et al., "Eksplorasi Nilai-Nilai Kesetaraan dalam Pendidikan Pesantren Mu'ādalah," Jurnal Pendidikan Agama Islam (Journal of Islamic Education Studies) 8, no. 1 (July 31, 2020): 39-58, https://doi.org/10.15642/jpai.2020.8.1.39-58.

4 Mufiqur Rahman, "Tradisi Nyabis sebagai Simbol Ethict of Care Kyai," Proceedings of Annual Conference for Muslim Scholars 3, no. 1 (November 26, 2019): 392-400.
} 
harus harmonis antar siswa. ${ }^{5}$ Penulis akan melihat eksistensi pesantren dalam tiga ranah tersebut di mana kiai menjadi figure dalam menjalankan tiga hal tersebut sehingga apapun yang dilakukan oleh kiai berpengaruh kepada tiga aspek tadi.

Fakta yang berkembang dan terjadi di masyarakat bahwa mereka memondokkan anaknya bukan atas dasar yang lain namun dengan dasar kharisma kiai yang memiliki pengaruh sentral. Kepribadian dan karakter Kiai menjadi faktor utama yang menentukan ketertarikan masyarakat untuk memasukkan anaknya ke pesantren. Itulah sebuah kepercayaan yang disebutkan Newton sebagai kepercayaan yang menciptakan sebuah daya tarik dalam sebuah interaksi. ${ }^{6}$ Pesantren telah memperkenalkan dirinya dengan berbagai bentuk atau model kiai, ada yang menggunakan sistem kiai modern seperti Pondok Modern Gontor, Pondok Pesantren Al-Amien Prenduan, ${ }^{7}$ dan ada juga pesantren yang masih mempertahankan corak tradisional dengan manajemen tradisional pula seperti Pesantren Sidogiri, dan seterusnya. Namun juga pesantren dalam konteks tata kelola memiliki dimensi berbeda, baik struktur pengurusan, manajemen santri dan menajemen ekonomi pesantren, yang mana kiai biasanya merangkap dan menjadi tokoh sentral dalam kehidupan pesantren.

Di samping ketokohan kiai sebagai figur sentral atau bahkan multi fungsi kiai di pesantren (baik sebagai pengasuh, pengurus dan pengawas) tercipta sebuah diskursus atau dengan hadirnya peraturan yang secara khusus memberikan aturan tentang tata kelola sebuah yayasan yang harus meliputi pembina, pengurus, dan pengawas dengan fungsi masing-masing yang tidak sama serta tidak boleh merangkap. ${ }^{8}$ Peraturan tersebut sebenarnya merupakan koreksi bagi pesantren untuk memperbaiki kepengurusan pesantrennya. Tapi peraturan ini agak sulit diterapkan di pesantren mengingat pesantren adalah sebuah lembaga pendidikan Islam yang dibentuk oleh masyarakat sendiri biasanya juga dengan kearifan pesantren dan masyarakat lokal. Di mana kearifan pesantren menjadikan kiai sebagai multi fungsi atau rangkap jabatan, baik sebagai pengasuh juga sebagai pengawas dan sekaligus pemangku kebijakan. Sikap terbuka dan tertutup sebuah pesantren ditentukan oleh kiai secara penuh. Artinya warna sebuah pesantren tergantung

\footnotetext{
5 Ach Sayyi, Menguak Nilai Pendidikan Islam Moderat di Pesantren Federasi Annuqayah Guluk-Guluk Sumenep," Turatsuna : Jurnal Keislaman dan Pendidikan 2, no. 2 (28 November 2020): 227-42.

${ }^{6}$ Martti Siisiäinen, "Two Concepts of Social Capital: Bourdieu vs. Putnam," International Journal of Contemporary Sociology 40 (January 1, 2003): 183-204.

7 Saifurrahman Nawawi, Nilai Pendidikan Sufistik KH. Imam Zarkasyi (Yogyakarta: UIN Suka Press, 2018), 5.

8 Ahmad Janan Asifudin, "Manajemen Pendidikan untuk Pondok Pesantren," Manageria: Jurnal Manajemen Pendidikan Islam 1, no. 2 (2016): 355-66, https://doi.org/10.14421/manageria.2016.12-10.
} 
pada karakter kiai. ${ }^{9}$ Dalam konteks kajian ini penulis akan mengangkat studi kasus di pesantren Nurul Huda Pakandangan Bluto Sumenep sebagai situs tunggal yang memfokuskan pada bagaimana seorang kiai pesantren mengambil sikap dan mengatur pesantren menjadi pesantren yang dekat dengan masyarakat dan terbuka untuk umat. Kemudian bagaimana kiai mengelola pesantren yang mengarusutamakan pendidikan toleransi dalam setiap proses pendidikan di pesantren.

\section{Metode Penelitian}

Metode penelitian yang digunakan adalah kualitatif dengan pendekatan fenomenologi. Penentuan informan dilakukan dengan strategi purposive sampling dan snowball sampling. Jejaring data dilakukan dengan observasi, wawancara mendalam, Focus Group Discussion (FGD) dan dokumentasi. Analisis data menggunakan analisis data Miles dan Huberman yaitu reduksi data, display data, dan verifikasi. ${ }^{10}$ Penelitian ini dilakukan di Pesantren Nurulhuda pakandangan Barat Bluto Sumenep Madura tahun 2020. Metode penelitian ini menggunakan penelitian kualitatif dengan pendekatan fenomenologi, jejaring data yang digunakan adalah wawancara dengan kiai, guru, dan santri dengan wawancara mendalam, kemudian observasi dilakukan secara partisipan kemudian jejaring juga dilakukan dengan data dokumen catatan kiai yang berhasil penulis temukan sebagai data pendukung. Selain tiga jejaring data tersebut juga dilakukan penguatan dengan FGD bersama dewan guru pesantren. Kemudian analisis data menggunakan reduksi data, display dan verifikasi.

\section{Hasil dan Pembahasan}

\section{Kiai Sebagai Tokoh Sentral}

Seperti yang disebut Hendry Thomas bahwa pengalaman toleransi ada pada simbol, praktek, dan tokoh. ${ }^{11}$ Kiai Saifurrahman Nawawi (1972-2015) adalah simbol, praktek, dan tokoh seperti yang disebut peneliti pusat studi Islam dan kenegaraan Indonesia karena Kiai Saifurrahman Nawawi adalah pimpinan atau pengasuh pesantren Nurulhuda Pakandangan Sumenep telah berhasil meletakkan sendi-sendi toleransi dalam setiap kebijakan atau menjaga hubungan sosial masyarakat sekitar pesantren dan tetap

\footnotetext{
${ }^{9}$ Asifudin.

${ }^{10}$ Sutopo, Metode Penelitian Kualitatif Tinjauan Teoritis dan Praktis (Surabaya: Visi Press Media, 2013), 41.

${ }^{11}$ Henry Thomas Simarmata et.al, Indonesia Zamrud Toleransi (Jakarta Selatan: PsiK-Indonesia, 2012).
} 
mengakomodasi kebutuham masyarakat dalam rangka melestarikan budaya, adat istiadat, dan kebiasaan masyarakat sekitar dengan senantiasa memberikan wawasan keilmuan dan kajian hakikat (ontologi) dari segala ritual keagamaan yang dilakukan.

Sikap toleran Kiai Saifurrahman dengan masyarakat dalam ritual-ritual seperti malam Sya'banan, Molodan, Tahlilan, Rabu Wekasan. Di mana terdapat beberapa kelompok yang menganggap hal itu sebagai bid'ah. Kiai Saifurrahman hadir memberikan toleransi dengan mempertahankan tradisi masyarakat dengan memberikan wawasan ilmu agama mengenai tradisi tersebut, berikut ini adalah pernyataan kiai ketika ada anggapan beberapa pihak yang menyangka Kiai Saifurrahman akan menghapus ritual malam Sya'banan:

"Saya hanya berniat untuk menambah pengetahuan masyarakat, supaya wawasan mereka bertambah. Saya tidak ada niat untuk menghapus Sya'banan di Pakandangan. Saya hanya ini masyarakat memiliki sikap kedewasaan dalam beragama. Tidak hanya ikut-ikutan. Tapi mereka tahu ilmunya." 12

Penjelasan di atas merupakan klarifikasi yang disampaikan tentang ritual malam sya'banan. Kiai Saifurrahman menekankan kepada masyarakat bahwa kiai ingin menciptakan kedewasaan masyarakat Pakandangan sehingga bertambah wawasan dan ilmu agamanya. sehingga dalam beragama, mereka tidak hanya ikut-ikutan (muqallid) yang dihina oleh Allah SWT. Tapi setidaknya mereka menjadi (muttabien) walaupun tidak menjadi (mujtahidin). Intinya setiap ritual masyarakat harus diberikan penjelasan baik, secara dalil sejarah maupun dalil Al-Qur'an dan Hadis.

Kiai alumni Gontor ini telah menampilkan potret dan wajah pendidikan toleransi melalui berbagai aspek, baik sosial (hubungan dengan masyarakat, wali santri dan tamu pesantren) maupun dalam setiap pengambilan keputusan atau kebijakan pesantren yang adil dan toleran sebagai bentuk dari menjaga hubungan dengan masyarakat. Kiai yang juga merupakan Majelis A’wan Pesantren Al-Amien Prenduan ini selalu menjaga prinsip moderat pesantren yaitu "berdiri di atas dan untuk semua golongan." Berdiri di atas artinya bersikap moderat dan tidak condong ke kanan secara dominan dan ke kiri secara dominan pula. Sikap toleran dan moderat terhadap partai politik tidak berarti fobia partai atau anti partai politik. Ini dibuktikan dari beberapa ceramahnya di berbagai kesempatan "saya mempersilahkan partai politik untuk bersilaturrahim dan berkunjung ke pesantren ini. Apalagi mereka mau membantu pesantren, saya sangat menyambut baik dengan

${ }^{12}$ Saifurrahman Nawawi, "Surat Penjelasan Masalah Malam Sya'banan Pakandangan, 15 Sya'ban," August $15,2008 / 1429 H$. 
syarat tidak mengikat. Tapi kalau saya yang datang dan meminta-minta supaya mereka membantu pesantren saya tidak mau." Ungkapan ini sering beliau sampaikan di hadapan seluruh guru dan santri baik dalam acara resmi pesantren seperti kuliah umum kepesantrenan maupun acara rutin di hadapan para guru setiap selesai salat subuh. Kemudian biasanya beliau mempertegas pernyataan itu dengan ungkapan berikut ini "Pesantren itu dibantu karena maju bukan maju karena dibantu."

Pernyataan itu mengandung banyak artikulasi positif terhadap keberlangsungan pesantren dan memperkuat prinsip moderat dan toleransi pesantren serta menanamkan kemandirian kepada santri dan guru-guru pesantren. Secara verbal kiai melakukan pendidikan dengan menanamkan jiwa kemandirian, bukan sikap kerdil dan pecundang dengan menjauhi sikap minta-minta. Sebagai seorang muballigh, Kiai Saifurrahman Nawawi melakukan dakwah dengan tidak membeda-bedakan, baik lembaga kecil, besar, birokrasi, partai politik, institusi, daerah kota, pedesaan, pulau, maupun pegunungan. Ini bentuk sikap toleran Kiai Saifurrahman Nawawi yang pernah menjadi juara MTQ Nasional. Baginya berdakwah adalah kewajiban dan amanah yang harus dilakukan selama masih mampu dan diberikan kesempatan Allah SWT. Beberapa hari sebelum wafat, Kiai Saifurrahman Nawawi masih berdakwah di salah satu daerah pegunungan (Prancak) dengan dijemput oleh pengundang. Biasanya Kiai Saifurrahman Nawawi tidak dijemput dan menyetir mobilnya sendiri.

\section{Tahapan Pendidikan Toleransi}

Ada beberapa tahapan pendidikan toleransi. Berikut ini penjelasan tentang tahapan pendidikan toleransi Pesantren Nurulhuda Pakandangan:

a. Tahap Perencanaan

Pendidikan toleransi di Pesantren Nurulhuda diawali dengan perencanaan yang telah dirancang dengan baik dan terarah dalam rangka menciptakan sebuah proses dan hasil yang ingin dicapai. Perencanaan terdiri dari aspek sebuah aktivitas yang telah hadir dan ditetapkan sebelumnya. Kemudian ada sebuah proses, dan juga hasil sesuai dengan target perumus. ${ }^{13}$ Perencanaan ini tidak lepas dari pertimbangan kiai walaupun memang rencana kegiatan telah dimusyawarahkan oleh dewan pengajar (asātidh) tetapi hasil akhir adalah meminta persetujuan kiai. Sehingga yang menjadi kontrol dan yang menimbang

13 Husaini Usman, "Manajemen: Teori, Praktik, dan Riset Pendidikan," Perpustakaan Kementerian Pekerjaan Umum dan Perumahan Rakyat, diakses 10 April 2021, https://pustaka.pu.go.id/biblio/manajemen-teori-praktik-dan-riset-pendidikan/59JGE. 
bahkan untuk menentukan rancangan tujuan dan misi pesantren serta karakter pesantren dipasrahkan kepada kiai. Di sini tampak bahwa kiai mengambil peran untuk mengontrol dan memosisikan diri sebagai konsultan dan penentu kebijakan rancangan pesantren. Perencanaan pendidikan toleransi telah disepakati oleh kiai dan dewan guru bahwa harus diimplementasikan dalam pembelajaran sebagai kurikulum tersembunyi (hidden curriculum) yang disampaikan pada setiap mata pelajaran secara integratif. ${ }^{14}$

\section{b. Tahap Pengorganisasian (organizing)}

Pengorganisasian di Pesantren Nurulhuda tidak terlepas dari tujuan yang telah dibuat bersama dengan kiai dan guru-guru pesantren, yaitu pengorganisasian berbasis kearifan pesantren. Di mana kiai menjadi setral dalam segala aspek. Kiai menentukan SDM para guru yang dipilih atas restu kiai, kemudian pemilihan ketua organisasi santri dipilih secara langsung oleh santri (demokratis) namun tetap terpimpin. Di sini pendidikan toleransi diimplementasikan karena tidak ada diskriminasi perbedaan sosial santri. Semua sama di hadapan hukum dan peraturan pesantren. ${ }^{15}$ Maksudnya kiai tetap memberi restu terhadap formatur terpilih. Demikian pula tentang pemilihan ketua pengurus lainnya berjalan di bawah restu kiai. Maka dalam pengorganisasian, kiai menjadi tokoh penting dan posisinya sangat menentukan.

c. Tahap Praktik

Kiai sebagai pengarah, memberikan pengarahan dan motivasi dalam aktivitas dan kegiatan pesantren, sebelum kegiatan berlangsung, kiai memberikan arahan dan motivasi untuk melakukan kegiatan, sehingga kegiatan pesantren yang akan dilakukan diharapkan berjalan secara sempurna. ${ }^{16}$

Keanekaragaman santri baik secara sosial dan budaya membuat pengarahan kiai tentang hidup rukun dan toleran menjadi sangat penting. Di sini diperlukan komunikasi kepemimpinan kiai yang menentukan keluwesan dan kebijaksanaan sehingga menghasilkan kehidupan santri yang baik dan harmonis. Kiai sebagai pengarah mengucapkan komunikasi yang baik. Kesuksesan sebuah organisasi ditentukan sepenuhnya oleh gaya komunikasi kiai yang lentur dan toleran sehingga gaya seperti itu dapat menghancurkan sekat ketidaknyamanan di bawahnya. ${ }^{17}$

\footnotetext{
${ }^{14}$ Mustar Yanto, Wawancara, March 12, 2020.

${ }^{15}$ Yanto.

${ }^{16}$ Zainullah Zainullah, Moh Mahfud, and Artamin Hairit, "Model Kepemimpinan Transformatif dalam Menciptakan Inovasi Pengembangan Kelembagaan Pendidikan Islam," Kuttab : Jurnal Ilmu Pendidikan Islam 4, no. 2 (September 28, 2020), https://doi.org/10.30736/ktb.v4i2.273.

${ }^{17}$ Usman, "Manajemen: Teori, Praktik, dan Riset Pendidikan."
} 
Praksis pendidikan toleransi kiai selain dalam berkomunikasi adalah kiai memberikan pendidikan toleransi dengan menerima tamu pesantren dari berbagai kelompok agama, etnis, dan budaya. Pesantren Nurulhuda mengadakan pembinaan bahasa asing dengan mendatangkan tutor dari mancanegara, dan beberapa tamu lain datang ke pesantren untuk studi banding. ${ }^{18}$

Praktik toleransi lainnya adalah konstruksi kurikulum pesantren dengan spirit toleransi yang ditanamnkan melalui pendekatan agama (fikih, tauhid, akhlak) melalui pembelajaran kitab kuning di mana spirit pendidikan toleransi disampaikan melalui pembelajaran di kelas. ${ }^{19}$

\section{d. Tahap Pengawasan}

Menurut Kanzie materi yang dikontrol atau diawasi adalah objek yang dilakukan oleh manajer. Di pesantren seluruhnya dalam konteks pengontrolan, akhirnya akan diajukan kepada kiai, ada beberapa lapis kontrol yang dilakukan di bawah kiai (pembantunya) sehingga apa yang disebut oleh Kanzie soal pengontrolan dilakukan oleh manajer dalam upaya mewujudkan apa yang telah direncanakan, ${ }^{20}$ di pesantren atas komando dari kiai sebagai manajer. dalam konteks ini yang menjadi manajer di pesantren ini adalah kiai yang dibantu oleh para guru senior. Pesantren Nurulhuda dalam melakukan controlling dan pengawasan pada setiap kegiatan pesantren, dalam observasi penulis adalah dalam kategori pengawasan santri kelas 1 SD dengan kelas 3 MTs diawasi oleh pengurus (dari kelas 6) sementara kelas 4 SD 6 langsung diawasi oleh para guru, dan semua laporan hasil kegiatan tersentralkankepada kiai sebagai manajer pesantren.

Salah satu yang diawasi adalah hukum dan peraturan pesantren di mana santri harus menaati disiplin sosial yang di dalamnya adanya saling menghormati dan toleran. Menjadi pelanggaran berat bila santri melanggar disiplin sosial seperti bullying, intimidasi, dan bertindak semena-mena yang merugikan pihak lain atau kelompok lain. ${ }^{21}$ Dari sini tahap pengawasan selalu dilakukan oleh para pengurus pesantren.

\footnotetext{
18 Suhaimi, Wawancara, March 20, 2020.

${ }^{19}$ Suhaimi.

${ }^{20}$ R. Alec Mackenzie, "The Management Process in 3-D," Harvard Business Review, November 1, 1969, https://hbr.org/1969/11/the-management-process-in-3-d.

${ }^{21}$ Ismail Makki, Wawancara, March 20, 2020.
} 


\section{Sistem Pendidikan yang Toleran}

Toleransi adalah wujud dari sikap kemauan (will) individu untuk bersahaja menerima orang lain yang berbeda secara bersahaja untuk menghormati tanpa menghukumi atau menghakimi. Toleransi menjadi kontributor dalam perumusan undangundang demokrasi dan HAM. Pengakuan secara jelas tentang kebhinekaan, bahwa perbedaan harus dipandang secara alamiah dan dalam lingkup perdamaian. Artinya toleransi harus ditanamkan dalam aspek cara berpikir dan sikap. Sayyi menyatakan bahwa salah satu sikap toleransi adalah tidak memberikan tekanan apapun kepada yang berbeda dan tidak memaksakan kehendak untuk mengikuti satu kepercayaan. ${ }^{22}$

Setelah kiai merevolusi sistem sekolah biasa (sistem pulang pergi atau santri kalong) kini menjadi sistem dengan manhaj mu'allimien ala gontor dengan pendidikan 24 jam. Sehingga menjadi sebuah pesantren visioner berwawasan progresif futuristik yang adaptif dengan kemajuan zaman. Manhaj tarbiyatul mua'llimien meramu IPTEK dan IMTAG menjadi komposisi integratif interkonektif. Nilai toleransi pada TMI Nurulhuda Pakandangan juga terlihat dalam kurikulum TMI (manahij tarbawiyah) bahwa kurikulum Nurulhuda Pakandangan bukan sekedar menyangkut struktur program pengajaran di kelas atau di luarnya, tetapi menyangkut aspek kehidupan para santri dan guru-guru; baik dalam menjalankan hubungan dengan Allah atau pun dengan sesama manusia dengan alam, baik aspek individual maupun sosial.

Semua kegiatan di kelas, masjid, asrama, kamar makan, kamar mandi, lapangan olahraga, dan sebagainya. Semuanya harus tercakup dalam kurikulum yang integratif dengan tetap mengikuti kurikulum nasional yang diramu dengan kurikulum pesantren. Karena itu, tidak berlebihan jika dikatakan bahwa kurikulum Nurulhuda Pakandangan adalah kurikulum yang mengedepankan kebutuhan alumninya (outcome) yang nantinya akan mengabdi kepada masyarakat. ${ }^{23}$

Nilai toleransi dalam memilih pengurus santri pesantren inilah yang menjadi pembeda Pesantren Nurulhuda Pakandangan dengan pesantren lainnya di Madura yang menjadikan pengasuhan santri harus dari golongan nasab/keturunan kiai. Hingga saat ini

\footnotetext{
22 Ach Sayyi, "Pendidikan Islam Moderat (Studi Internalisasi Nilainilai Islam Moderat di Pesantren Annuqayah Daerah Lubangsa dan Pesantren Annuqayah Daerah Latee Guluk-guluk Sumenep), September 21, 2020, http://repository.unisma.ac.id/handle/123456789/716; A. Jauhar Fuad, "Pembelajaran Toleransi: Upaya Guru Pendidikan Agama Islam Dalam Menangkal Paham Radikal Di Sekolah," in Proceedings of Annual Conference for Muslim Scholars, 2018, http://proceedings.kopertais4.or.id/index.php/ancoms/article/view/159.

${ }^{23}$ Abd. Syakur, Manajemen Program Santri Mengabdi untuk Kemajuan Negeri, January 24, 2020.
} 
pemilihan pengasuh santri (pengurus organisasi santri) atau dari dewan guru, ditentukan bukan berdasarkan keturunan kiai. Falsafah yang sering diungkapkan oleh pesantren ini adalah "patah tumbuh hilang berganti" adalah satu falsafah yang menjadi prinsip Pesantren Nurulhuda sebagai lembaga pendidikan kepemimpian dan keguruan (mua'llimien). ${ }^{24}$

Kebijakan kurikulum integratif Kiai Saifurrahman dengan memasukkan beberapa materi pembelajaran yang mengandung nilai pendidikan toleransi yang ditemukan dalam studi ini adalah merupakan jawaban kongkret dari teori toleransi Giacomo dan Jeniver yang mengatakan bahwa pendidikan toleransi itu seperti ekonomi investasi di mana anak sejak dini telah diajarkan beberapa pembelajaran yang menguatkan tentang nilai toleransi, seperti menerima diversitas atau kebhinekaan, pengampunan, dan kasih sayang. Inilah beberapa materi pembelajaran di kelas yang menguatkan nilai toleransi; dalam ilmu fikih menggunakan fikih Syafi'i. Dalam Ilmu tauhid menggunakan Asy'arie dan dalam ilmu akhlak menggunakan akhlak Al-Ghazali.

Kiai Saifurrahman Nawawi dalam kebijakannya menentukan kurikulum banyak mengadopsi kurikulum Gontor dengan tetap mempertimbangkan beberapa kurikulum yang sesuai dengan masyarakat sekitar. Terutama dalam bidang tauhid dan fikih. Kiai Saifurrahman dan berprinsip sama dengan sebuah pendapat Imam al-Syafi'I " pendapatku benar tapi mungkin salah" (ra'yi sawabun yahtamilu al-khata'a) dan pendapatnya salah mungkin juga benar (wa ra'yu ghayri khata'un yahtamilu al-sawaba). Baginya tidak ada kebenaran mutlak, bahkan dirinya juga bisa saja salah. Walaupun Imam al-Sy-afi'i pada sisi lainnya tidak mau terjebak dalam paham relativisme.

Konsep dan pemikiran ini menjadi sebuah pemikiran konsep yang baik dalam formulasi karakter toleran dan moderat versi Imam al-Syafi'i yang memberi inspirasi kepada Kiai Saifurrahman Nawawi bahwa “penyesatan” terhadap orang yang berbeda pendapat adalah tindakan yang tidak etis. Kiai Saifurrahman Nawawi berhasil menjadikan fikih menjadi dialogis menutup kevakuman dan stagnansi berpikir. Dalam beberapa kesempatan, Kiai Saifurrahman Nawawi selalu membuka wawasan keagamaan guru-guru dan santri tentang sikap dan nilai toleransi yang sesuai dengan ajaran wahyu dan profetik.

24 "Tarbiyatul Mu'allimien Al-Islamiyah (TMI) | Pondok Pesantren Al-Amien Prenduan," accessed April 10, 2021, https://al-amien.ac.id/lembaga-pendidikan/tmi/. 


\section{Pendidikan Toleransi dalam Islam}

Sebagaimana disebutkan oleh Syauqi dalam Ali Ridho bahwa yang terpenting dalam pendidikan toleransi adalah berdamai dan pemberian maaf kemudian berlaku baik. ${ }^{25}$ Pendidikan toleransi di pesantren ini mengarusutamakan tiga karakter tersebut, yaitu berdamai dengan masyarakat dengan mengakomodasi seluruh kegiatan sosial keagamaan, dan pemberian maaf kepada santri dalam pemberian sanksi dan berlaku baik pada setiap perbedaan yang diatur dalam disiplin sosial pesantren. Tolchah Hasan memberikan penguatan tentang definisi toleransi yaitu toleransi merupakan sikap yang paling dasar yang diajarkan dalam Islam baik dalam sejarah peradaban Islam maupun secara wahyu. Hasan menyebutkan bahwa toleransi merupakan ajaran Islam, sehingga Islam dinyatakan oleh banyak kalangan sebagai agama kasih sayang, banyak ayat atau dalil naqli yang bicara seputar toleransi di antaranya adalah Q.S. Al-Imran, 159. Ayat yang menekankan pada sikap lemah lembut kepada sesama dalam sebuah perbedaan. Menurut mufassir dalam Tholhah menyebutkan bahwa ayat di atas turun kepada rasulullah saat perang Uhud, sebagaimana diketahui bahwa sebelumnya Nabi tidak ingin perang, namun kesimpulan musyawarah mayoritas sahabat menyetujui dan menginginkan perang, nabi mengikuti keputusan musyawarah. Maka terjadilah perang.

Nabi Muhammad SAW mengintruksikan untuk tidak meninggalkan posisi perang saat kaum muslimin dalam posisi menang sementara. Pasukan muslim tergoda dengan kemenangan itu, mereka pergi meninggalkan medan perang dan berlomba-lomba mengambil rampasan perang. Tiba-tiba hal ini menjadi kesempatan musuh untuk melakukan serangan balasan. Barisan pasukan Islam menjadi tak terkendali, kacau dan tidak tersusun rapi sebagaimana sebelumnya. Ini menyebabkan Rasulullah terluka dan banyak korban. ${ }^{26}$

Pastinya Rasulullah berada dalam kekecewaaan yang sangat. Nabi pasti marah. Namun Nabi masih bisa menahan amarahnya kemudian menahan kekecewaannya. Nabi bersikap ramah dan lemah lembut terhadap mereka yang tidak patuh kepada perintahnya, masih memberikan maaf mereka dan tetap mengajak mereka bermusyawarah. Inilah sikap beliau yang pemaaf dan toleran itu mendapat apresiasi dari Allah melalui wahyu. ${ }^{27}$

\footnotetext{
25 Ali Ridho, "Internalisasi Sikap Toleransi Siswa Madrasah Di Lingkungan Vihara Avalokitesvara," Fikrotuna 8, no. 2 (December 31, 2018): 1011-30, https://doi.org/10.32806/jf.v8i2.3293.

26 Mohammad Tholchah Hasan, "Pengertian Dasar Tentang Multikulturalisme Dan Pendidikan Multikultural” (Bahan Kuliah Program Doctor PAI Multikultural Unisma, Malang, 2017).

${ }^{27}$ Hasan.
} 
Di pesantren ini pendidikan toleransi tidak dapat dilepaskan dari spirit karakter Nabi Muhammad SAW. Sebagai rujukan dan teladan, spirit untuk mengutamakan pemberian maaf diberikan kepada pelanggar disiplin sosial pesantren serta selalu diadakan musyawarah dalam pengambilan keputusan. Sebagaimana pesantren meletakkan disiplin dan hukum tidak ada kekerasan di pesantren menjadi sesuatu hal yang sangat ditekankan. Sehingga tidak ada kekerasan di pesantren apalagi tawuran.

Imam Al-Ghazali dalam Irwan Masduqi, mengingatkan bahwa tindakan main hakim sendiri dengan menggunakan kekerasan, apalagi tawuran, adalah tindakan yang tidak dibenarkan meskipun dengan dalil amar ma'ruf nahi munkar. Imam al-Ghazali menulis, “Telah saya jelaskan tingkatan-tingkatan amar ma'ruf nahi munkar: (1) memberi tahu; (2) menasehati; (3) teguran dengan kata-kata keras, dan; (4) mencegah secara paksa dengan sanksi hukuman. Tingkatan pertama dan kedua boleh dilakukan oleh warga sipil maupun pemerintah. Tingkatan ketiga dengan teguran keras seperti kata-kata 'wahai orang zalim dan wahai orang yang tak takut tuhan' boleh dilakukan oleh warga sipil dan pemerintah apabila tidak menyebabkan fitnah kepada orang lain. Adapun tingkatan keempat hanya boleh dilakukan oleh pemerintah." 28

Ada sejumlah fakta sejarah lain yang dapat dijadikan sikap dan karakter yang menarik yang ditunjukkan oleh Nabi Muhammad SAW yang dijadikan nilai karakter toleran di pesantren. Pertama ketika Abdullah bin Ubay sebagai tokoh orang-orang munafik Madinah meninggal dunia, lalu putranya menghadap Rasulullah memberi tahu, kemudian berkata: Abdullah bin Ubay telah meninggal, saya mohon Rasulullah berkenan memberikan gamis paduka dan saya akan mengafani beliau dengan gamis itu. Maka beliau mengambil gamis itu dan memberikannya kepada putra Abdullah bin Ubay. Kedua, Seorang remaja Yahudi sedang sakit, maka Nabi Muhammad SAW membesuknya, beliau duduk dekat kepalanya. ${ }^{29}$ Karakter ini menjadi spirit pesantren ini dalam melakukan peran sosial di masyarakat dan juga kepada santri.

Sebagaimana dalam Pandangan Al-Ghazali pendidikan toleran, inklusif dan humanis yang dicontohkan dan diajarkan Nabi. Diceritakan bahwa ada seorang Baduwi yang datang ke masjid lalu mengencingi masjid Nabawi di hadapan Nabi. Para sahabat secara spontan emosi tetapi anehnya Muhammad SAW justru melarang para sahabatnya melakukan cara kekerasan untuk menghalanginya kencing. Sahabat tidak terima dan

\footnotetext{
${ }^{28}$ Irwan Masduqi, "Deradikalisasi Pendidikan Islam Berbasis Khazanah Pesantren," Jurnal Pendidikan Islam 2, no. 1 (2013): 1-20, https://doi.org/10.14421/jpi.2013.21.1-20.

${ }^{29}$ Hasan, "Pengertian Dasar Tentang Multikulturalisme Dan Pendidikan Multikultural."
} 
melakukan protes, Sahabat berkata "Tetapi ini adalah masjid yang tak layak dikotori dan dikencingi”. Lalu Nabi berkata, “Qarrib-hu wa la tunaffir-hu, ” Dekatilah dia secara baikbaik dan jangan dengan kekerasan agar tidak lari dari Islam.. ${ }^{30}$ Di sini tampak kelembutan hati Nabi yang harus diikuti oleh umat Islam. Nabi bagaimanapun tidak menyukai kelakuan Arab Badui itu, tetapi pelajaran yang dapat dipetik adalah bagaimana mengajarkan mengatur nafsu amarah sehingga tidak dilalui dengan cara kekerasan atas nama agama seperti yang disaksikan dewasa ini di mana banyak aktivis Islam melakukan kekerasan atas nama agama.

Sikap Nabi Muhammad SAW yang lemah lembut dan tidak ekstrim ini tidak dijadikan teladan oleh kelompok radikalis hari ini. Selain itu Nabi sebagaimana disebutkan dalam hadis Sahih Muslim juga mendidik umatnya prinsip toleran. Di mana suatu hari ada jenazah dipanggul melewati depan Nabi lalu Nabi berdiri untuk menghormatinya. Spontan ada seseorang memberi tahunya bahwa jenazah tersebut adalah Yahudi, tetapi kenapa Nabi berdiri menghormatinya? Nabi menjawab, "Bukankah dia juga manusia?" Jawaban Nabi ini mengajarkan kepada umatnya agar menghormati manusia tanpa memandang latar belakang ras dan agamanya. ${ }^{31}$

\section{Kesimpulan}

Kiai pesantren Nurulhuda Pakandangan menjadi top manajer atau sentral manajemen dalam pendidikan toleransi, baik sebagai perancang, pelaksana dan pengontrol jalannya pendidikan di pesantren. Kiai adalah gelar yang diberikan oleh masyarakat kepada seorang ahli agama Islam yang memiliki atau yang menjadi pimpinan pesantren dan mengajar kitab-kitab Islam klasik kepada para santri memberikan sentuhan pendidikan yang baik dan komunikasi yang baik pula dalam mengatur kehidupan santri yang beragam.

Penelitian ini menghasilkan sebuah model pendidikan toleransi yaitu model kiai centered atau berpusat pada keteladan kiai. Pertama kiai sebagai pengarah dan perumus memberikan rancangan dan rencana pendidikan berbasis pada pendidikan multi budaya dan sosial santri yang beragam. Tahap pelaksanaan pendidikan toleransi dimulai pada tahapan desain dan rancangan pembelajaran. Pembelajaran toleransi disampaikan di kelas secara integratif dengan semua mata pelajaran, guru harus menyampaikan pesan toleransi

\footnotetext{
${ }^{30}$ Masduqi, "Deradikalisasi Pendidikan Islam Berbasis Khazanah Pesantren."

${ }^{31}$ Masduqi.
} 
pada setiap mengajar. Kemudian praktik toleransi diakomodasi kiai dalam kegiatan santri dan masyarakat, kiai juga mengakomodasi tradisi masyarakat.

Beberapa hal yang dapat penulis sarankan setelah melakukan kajian ini di antaranya adalah; pesantren dengan manajemennya memang memiliki kekhasan sendiri dalam pendidikan toleransi namun menurut penulis setidaknya kiai dalam menentukan manajemen pesantren setidaknya didukung oleh beberapa lapisan guru-guru dalam merencanakan dan kontrol dan bimbingan. Hal ini untuk mengurangi beban kiai yang terlalu menumpuk.

\section{Referensi}

Asifudin, Ahmad Janan. "Manajemen Pendidikan Untuk Pondok Pesantren.” Manageria: Jurnal Manajemen Pendidikan Islam 1, no. 2 (2016): 355-66. https://doi.org/10.14421/manageria.2016.12-10.

Fuad, A. Jauhar. "Pembelajaran Toleransi: Upaya Guru Pendidikan Agama Islam dalam Menangkal Paham Radikal di Sekolah." In Proceedings of Annual Conference for Muslim Scholars, 561-71, 2018. http://proceedings.kopertais4.or.id/index.php/ancoms/article/view/159.

Habibi, Mohammad Mizan. "Islamic Education Curriculum Framework Development Based on Multicultural Values," 3:25-28. 5, 2017. http://ijmas.iraj.in/paper_detail.php?paper_id=8208\&name=Islamic_Education_ Curriculum_Framework_Development_Based_on_Multicultural_Välues.

Hasan, Mohammad Tholchah. "Pengertian Dasar tentang Multikulturalisme dan Pendidikan Multikultural.” Bahan Kuliah Program Doktor PAI Multikultural Unisma, Malang, 2017.

Mackenzie, R. Alec. "The Management Process in 3-D." Harvard Business Review, November 1, 1969. https://hbr.org/1969/11/the-management-process-in-3-d.

Masduqi, Irwan. "Deradikalisasi Pendidikan Islam Berbasis Khazanah Pesantren.” Jurnal Pendidikan Islam 2, no. 1 (2013): 1-20. https://doi.org/10.14421/jpi.2013.21.120.

Nawawi, Saifurrahman. Nilai Pendidikan Sufistik KH. Imam Zarkasyi. Yogyakarta: UIN Suka Press, 2018.

—. "Surat Penjelasan Masalah Malam Sya'banan Pakandangan, 15 Sya'ban," August 15, 2008/1429H.

Rahman, Mufiqur. "Tradisi Nyabis sebagai Simbol Ethict of Care Kyai.” Proceedings of Annual Conference for Muslim Scholars 3, no. 1 (November 26, 2019): 392-400.

Rahman, Mufiqur, Maskuri Bakri, Hasan Busri, Zainullah Zainullah, and Roro Kurnia Nofita Rahmawati. "Eksplorasi Nilai-Nilai Kesetaraan dalam Pendidikan Pesantren Mu'ādalah." Jurnal Pendidikan Agama Islam (Journal of Islamic Education Studies) 8, no. 1 (July 31, 2020): 39-58. https://doi.org/10.15642/jpai.2020.8.1.39-58. 
Ridho, Ali. "Internalisasi Sikap Toleransi Siswa Madrasah di Lingkungan Vihara Avalokitesvara." Fikrotuna 8, no. 2 (December 31, 2018): 1011-30. https://doi.org/10.32806/jf.v8i2.3293.

Sayyi, Ach. "Menguak Nilai Pendidikan Islam Moderat di Pesantren Federasi Annuqayah Guluk-Guluk Sumenep." Turatsuna : Jurnal Keislaman dan Pendidikan 2, no. 2 (November 28, 2020): 227-42.

. "Pendidikan Islam Moderat (Studi Internalisasi Nilai-nilai Islam Moderat di Pesantren Annuqayah Daerah Lubangsa dan Pesantren Annuqayah Daerah Latee Guluk-guluk Sumenep)," $\quad$ September 21, 2020. http://repository.unisma.ac.id/handle/123456789/716.

Siisiäinen, Martti. "Two Concepts of Social Capital: Bourdieu vs. Putnam.” International Journal of Contemporary Sociology 40 (January 1, 2003): 183-204.

Simarmata, Henry Thomas et.al. Indonesia Zamrud Toleransi. Jakarta Selatan: PsiKIndonesia, 2012.

Sutopo. Metode Penelitian Kualitatif Tinjauan Teoritis dan Praktis. Surabaya: Visi Press Media, 2013.

Syakur, Abd. Manajemen Program Santri Mengabdi untuk Kemajuan Negeri, January 24, 2020.

"Tarbiyatul Mu'allimien Al-Islamiyah (TMI) | Pondok Pesantren Al-Amien Prenduan." Accessed April 10, 2021. https://al-amien.ac.id/lembaga-pendidikan/tmi/.

Usman, Husaini. "Manajemen: Teori, Praktik, dan Riset Pendidikan." Perpustakaan Kementerian Pekerjaan Umum dan Perumahan Rakyat. Accessed April 10, 2021. https://pustaka.pu.go.id/biblio/manajemen-teori-praktik-dan-risetpendidikan/59JGE.

Zainullah, Zainullah, Moh Mahfud, and Artamin Hairit. "Model Kepemimpinan Transformatif dalam Menciptakan Inovasi Pengembangan Kelembagaan Pendidikan Islam." Kuttab : Jurnal Ilmu Pendidikan Islam 4, no. 2 (September 28, 2020). https://doi.org/10.30736/ktb.v4i2.273. 